\title{
РУДНО-МЕТАСОМАТИЧЕСКАЯ ЗОНАЛЬНОСТЬ МОЛИБДЕН-ПОРФИРОВОЙ СИСТЕМЫ АКСУ (Северо-ВостоК АЗИи)
}

\author{
Соцкая О. Т., Михалицына Т. И., Савва Н. Е., Горячев Н. А., Маматюсупов В. Т., \\ Семымев Ф. И., Малиновский М. А.
}

\author{
ФГБУН Северо-Восточный комплексный научно-исследовательский институт \\ им. Н. А. Шило ДВО РАН, г. Магадан \\ E-mail: sotskaya@neisri.ru
}

\begin{abstract}
Приведены данные комплексного изучения метасоматитов Мо-порфировой системы месторождения Аксу в Коркодоно-Наяханской зоне магматической активизации. Показана асимметричность ореола метасоматических изменений вокруг порфировой системы, связанная с тектоническо-блоковым строением территории. Ядро системы выведено на поверхность и находится в ореоле калишпат-мусковитовых метасоматитов, северо-западный блок приподнят и характеризуется высокотемпературными эпидот-биотитовыми и эпидот-пироксеновыми пропилитами, а в юго-восточном блоке отмечается последовательный переход от калишпатсерицитовых метасоматитов до фрагментов аргиллизитовых. Установленная зональность подтверждена геохимическими ассоциациями и типами оруденения с северо-запада на юговосток: $\mathrm{Au}-\mathrm{Bi}(\mathrm{As}, \mathrm{Cu})$, рудопроявление Солнечное; в центре $\mathrm{Mo}(\mathrm{Cu}, \mathrm{Au})$ - месторождение Аксу, на юго востоке - $\mathrm{Ag}-\mathrm{Pb}-\mathrm{Zn}(\mathrm{Cu}, \mathrm{Bi}, \mathrm{As}, \mathrm{Au})$, рудопроявление Высокое.
\end{abstract}

Ключевые слова: метасоматиты, Мо-порфировая система, геохимия, Магаданская область.

DOI: 10.34078/1814-0998-2021-3-3-17

\section{ВВЕДЕНИЕ}

Медно-порфировые и молибден-порфировые месторождения являются важным промышленным типом и имеют большие запасы при малых содержаниях полезных компонентов. Они служат источником меди, молибдена, а также олова, цинка, свинца, золота, серебра и других металлов. Этот тип месторождений, считавшийся не характерным для Магаданской области, в настоящее время приобретает все большее значение, о чем свидетельствует возобновление прогнозных и поисковых исследований ныне приоритетного для региона направления. Активным периодом по обнаружению медно-молибденовых месторождений являлись 1970-1980-е гг, когда были обнаружены и охарактеризованы медные объекты Перекатный, Уптар, Лора, Прямой, Тальниковый и др. (Скибин, 1982). Наиболее изучено медно-порфировое месторождение Песчанка (Олойский вулканический пояс), характеризующееся метасоматической и рудной зональ-

(с) Соцкая О. Т., Михалицына Т. И., Савва Н. Е., Горячев Н. А., Маматюсупов В. Т., Семышев Ф. И., Малиновский М. А., 2021 ностью, свойственной порфировым системам (Читалин и др., 2016). По данным региональных и мировых исследований для всех порфировых месторождений мира зафиксирована четкая минералого-геохимическая и метасоматическая зональность, имеющая важное значение при поисках и разведке подобных месторождений (Sillitoe, 1973, 2010; Кривцов, 1983; Кривцов и др., 1986). Цель данной работы состоит в выявлении метасоматической, минеральной и геохимической зональности по результатам комплексных исследований горных пород и руд в пределах предполагаемой Аксуйской молибден-порфировой системы (далее АМПС).

Район исследований приурочен к КоркодоноНаяханской металлогенической зоне северозападного простирания; расположен дискордантно по отношению к Удско-Мургальскому металлогеническому поясу, специализированному на $\mathrm{Cu}$ и Мо (Парфенов, 1984). На указанной площади, кроме молибден-порфирового месторождения Аксу, расположены пространственно сближенные с ним рудопроявления золото-висмутового и серебро-полиметаллического типов Солнечное и Высокое. 


\section{ФАКТИЧЕСКИЙ МАТЕРИАЛ И МЕТОДЫ ИССЛЕДОВАНИЙ}

В основу статьи положены материалы, полученные авторами при полевых и лабораторных исследованиях в СВКНИИ ДВО РАН (г. Магадан). Образцы были отобраны из естественных обнажений по субширотному и северозапад - юго-восточному профилям, пересекающим всю структуру АМПС. Выполнены оптико-минералогические исследования (поляризационный микроскоп Axioplan Imagin) 131 шлифа и 200 аншлифов; проведены специальные электронно-микроскопические наблюдения на аппаратно-программном комплексе QEMSCAN (Австралия, Германия) 11 препаратов (шлифы на эпоксидной смоле).

Геохимическую зональность АМПС определяли по 149 штуфным пробам. Содержания химических элементов в пробах устанавливали эмиссионным количественным спектральным анализом (в том числе серебра), золота - атомноабсорбционным методом. Выделение ассоциаций химических элементов проводили методами математической статистики - корреляционным и факторным анализами (Китаев, 1990).

Минеральный состав метасоматитов и руд определяли в автоматическом режиме на аппаратно-программном комплексе QEMSCAN (фирмы FEI), представляющем собой сканирующий электронный микроскоп EVO-50 (Carl
Zeiss), оснащенный четырьмя энергодисперсионными спектрометрами AXS XFlash (фирмы Bruker) и специальным программным обеспечением, которое автоматизирует систему анализа минерального состава руд и позволяет делать его количественную оценку по картам, выполненным в характеристических рентгеновских лучах. Применялся режим Frame Scan - покадровое сканирование с получением минеральной карты (Рид, 2008). Для изучения состава отдельных частиц использовали систему рентгеновского микроанализа Quantax (Bruker), входящую в состав комплекса. Условия проведения измерений: ускоряющее напряжение 25 кВ, ток в ведерке Фарадея - 5 нА.

\section{ГЕОЛОГИЧЕСКОЕ СТРОЕНИЕ РУДНОГО УЗЛА}

Рассматриваемая территория находится в пределах Коркодоно-Наяханской минерагенической зоны Охотско-Чукотской металлогенической провинции и охватывает западную часть Коркодонского рудного узла (Кузнецов и др., 1998). Рудный узел включает в себя Мо-порфировое месторождение Аксу, а также рудопроявления Солнечное - Au-редкометалльного и Высокое - Ag-полиметаллического типов в приконтактовой зоне гранитоидных массивов Незаметный, Безымянный и Сабля (рис. 1).

Puc. 1. Геологическая карта предполагаемой молибден-порфировой системы Аксу с точками отбора проб (по материалам В. К. Рочевой, Д. С. Писаренко, 2013 г., с изменениями и дополнениями). Условные обозначения: 1 - четвертичная система; 2, 3 - юрская система, нижний - средний отделы (бургагчанская толща): 2 - средняя подтолща, вулканомиктовые песчаники и алевролиты со слоями аргиллитов и туфов; 3 - нижняя подтолща, аргиллиты, углистые алевролиты с прослоями туффитов, гравелитов, линзами конгломератов; 4, 5 - триасовая система, верхний отдел: 4 - сугойская толща, аргиллиты, алевролиты, песчаники, туффиты с прослоями туфопесчаников, известковых песчаников; 5 - хурканская толща, алевролиты, аргиллиты с прослоями песчаников; 6-9 - палеогеновые и позднемеловые интрузивные образования: $6, a$ - палеогеновые дайки андезибазальтов, базальтов $(\beta)$, андезитов $(\alpha) ; 6, \sigma$ - неразделенные субвулканические дайки андезитов; 7, $a$ - неразделенные интрузивные образования; 7, 6 - тело гранитпорфиров, дайки гранитов, гранодиоритов $(\gamma \delta)$, диорит-порфиритов, контур рудопроявления; 8 наяханский интрузивный комплекс; 9, a- массивы гранодиоритов, штоки гранитов; дайки гранит-порфиров $(\gamma \pi)$, гранит-аплитов $(\rho) ; 9, \sigma$ - штоки диоритов, диорит-порфиритов $(\delta \pi)$, кварцевых диоритов (q $\delta)$; дайки диорит-порфиритов $(\delta \pi) ; 10$ - минерализованные зоны дробления, зоны метасоматитов и зоны прожилкования (1), жилы (2), свалы (3) кварцевого (q), сульфидно-кварцевого (sl-q), сульфидного (sl), сульфидно-хлорит-кварцевого (sl-cl-q), хлорит-кварцевого (cl-q) состава; 11-21 - метаморфические и метасоматические изменения (точки отбора проб): 11 - Q, 12 - Q-Fsp, 13 - Q-Ab, 14 - Q-Cl-Ac, 15 - Q-Cc, 16 - Ep-Px, 17 - Q-Ser, 18 - Q-Bt, 19 - Q-Mu, 20 - Mu-Fsp, 21 - шлифы, изученные методом автоматической минералогии; 22 - геологические границы между разновозрастными образованиями: $a$ - достоверные, $\sigma$ - предполагаемые; 23 - тектонические нарушения: $a$ - установленные, $\sigma$ - второстепенные; 24 - контур рудопроявления, 25 - контур месторождения

Fig. 1. Geological map of the assumed Aksu molybdenum-porphyre system with sampling points (after V. K. Rocheva, D. S. Pisarenko, 2013, added and amended). Legend: 1 - Quaternary system; 2, 3 - Jurassic system, lower to middle division (Burghagchan mass): 2 - middle submass: volcanomictic sandstones and aleurolites with layers of argillites and tuffs; 3 - lower submass: argillites, carbonaceous aleurolites with interbeds of tuffites, gravelstones, conglomerate lenses; 4, 5 - Triassic system, upper division: 4 - Sugoy mass: argillites, aleurolites, sandstones, tuffites with interbeds of tuffaceous and lime sandstones; 5 - Khurkan mass: aleurolites, argillites 


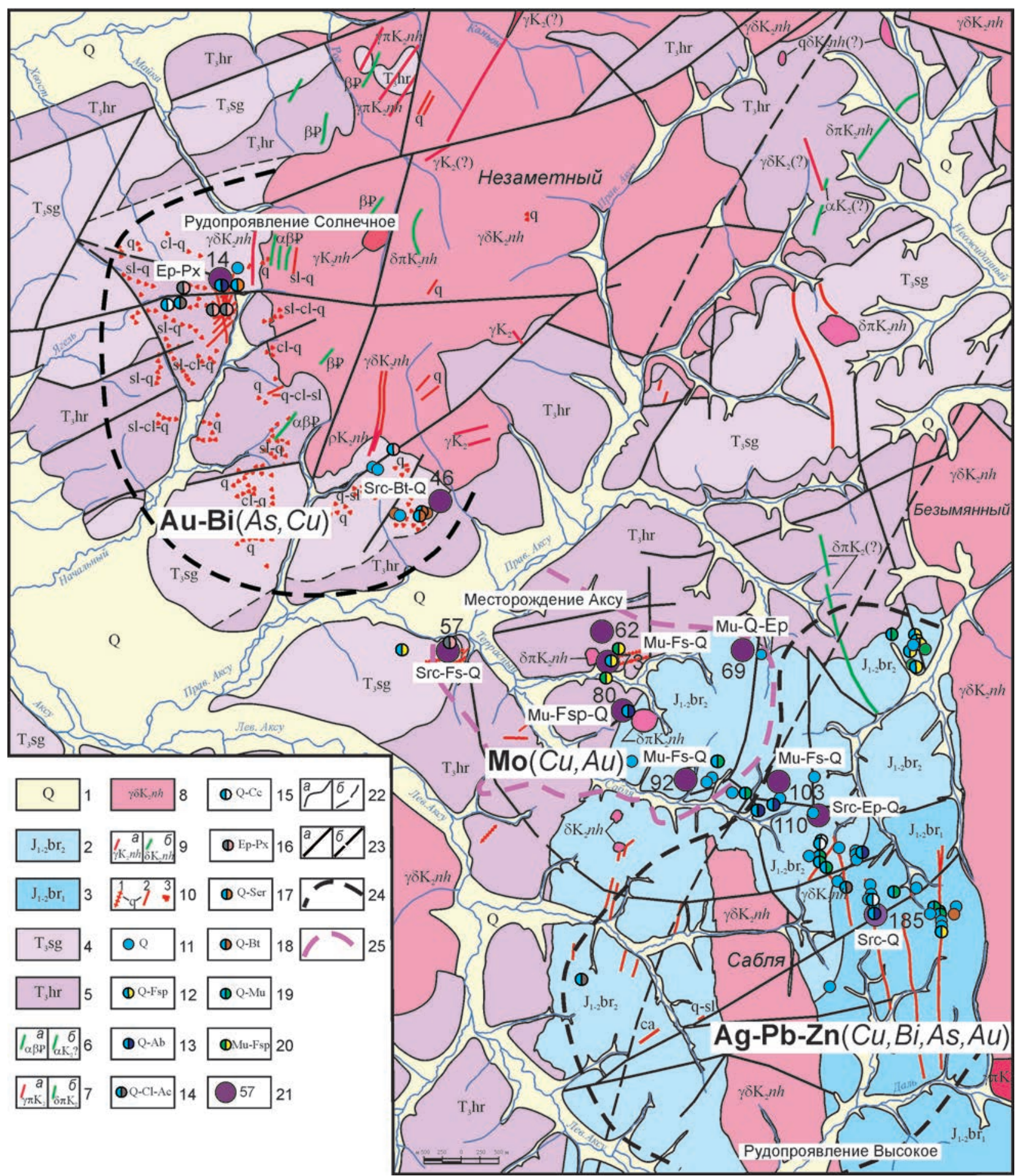

with interbeds of sandstones; 6-9-Late Cretaceous intrusive formation: 6, $a$ - paleogenic dikes of andesibazalts, basalts $(\beta)$, andesites $(\alpha) ; 6, \sigma$ - undivided subvolcanic dikes of andesites; $7, a$ - undivided intrusive formations; $7, \sigma$ - body of granite porphyries, dikes of granites, granodiorites $(\gamma \delta)$, diorit-porphyrites, ore occurrence contour; 8 - Nayakhan intrusive complex; 9, $a$ - massifs of granodiorites, granite stocks; dikes of granite-porphyries $(\gamma \pi)$, granite-aplites $(\rho) ; 9, \sigma-$ stocks of diorites, of diorite porphyrites $(\delta \pi)$, and of quartz diorites $(\mathrm{q} \delta)$; dikes of diorite-porphyrites $(\delta \pi) ; 10$ - mineralized crushing zones, metasomatite zones, and veinlet zones (1), veins (2), dumps (3) of quartz (q), sulfide-quartz (sl-q), sulfide (sl), sulfide-chlorite-quartz (sl-cl-q), and chlorite-quartz (cl-q) composition; 11-21 - metamorphic and metasomatic changes (sampling points): $11-\mathrm{Q}, 12-\mathrm{Q}-\mathrm{Fsp}, 13-$ Q-Ab, 14 - Q-Cl-Ac, 15 - Q-Cc, 16 - Ep-Px, 17 - Q-Ser, 18 - Q-Bt, 19 - Q-Mu, 20 - Mu-Fsp, 21 - thin sections studied by automatic mineralogy; 22 - geological boundaries between formations of different ages: $a$ - reliable, $\sigma$ - assumed; 23 - tectonic violations: $a$ - proved, $\sigma$ - minor; 24 - ore occurrence contour, 25 - contour of the deposit 
По данным В. В. Акинина и др. (2019) установлено, что диорит-гранодиоритовый магматизм наяханского комплекса Коркодоно-Наяханской зоны Охотско-Чукотского вулканогенного пояса (ОЧВП) и связанная с ним молибденовая минерализация имеют позднемеловой сантонский возраст, и это говорит об их генетическом родстве в единой рудно-магматической системе.

Вмещающие породы представлены верхоянским комплексом триасовой (хурканская $\mathrm{T}_{3} \mathrm{hr}$, сугойская $\mathrm{T}_{3} \mathrm{sg}$ толщи) и юрской (бургагчанская толща $\mathrm{J}_{1-2} \mathrm{br}_{2}$ ) систем, относящихся к БалыгычаноХетагчанской структурно-фациальной зоне, Хетагчанской подзоне (Кузнецов и др., 1998). Хурканская толща (мощность 450-500 м) сложена переслаивающимися алевролитами и аргиллитами с прослоями песчаников; сугойская толща (мощность 850-950 м) представлена кремнистыми туфоаргиллитами, псаммитовыми и алевролитовыми туффитами, ракушечниками и глинистыми известняками. Верхнетриасовые отложения характеризуются переходными к флишоидному типу разрезами. Юрские отложения представлены бургагчанской толщей, выполняющей Право-Хетагчанскую брахисинклиналь. Отложения $\mathrm{J}_{1-2} \mathrm{br}_{2}$ имеют значительную мощность и литологическую разнородность. В нижней ее части преобладают глинистые породы, средняя подтолща представлена преимущественно туфопесчаниками и служит маркирующим горизонтом, верхнюю подтолщу слагают переслаивающиеся аргиллиты, алевролиты и песчаники.

Осадочные породы смяты в складки преимущественно северо-восточного и субширотного направлений и прорваны биотит-роговообманковыми гранитоидами наяханского комплекса позднемелового возраста, а в центральной части рудоносной структуры - небольшими штоками диорит-порфиритов. Палеогеновые дайки базальтов и андезибазальтов в истоках р. Аксу прорывают гранитоиды массива Незаметный. Отложения повсеместно в различной степени преобразованы регионально-метаморфическими, контактово-метаморфическими и гидротермально-метасоматическими процессами.

В структурном плане территория приурочена к зоне влияния Коркодоно-Наяханского глубинного долгоживущего магмо- и рудоконтролирующего разлома. Его простирание северо-западное, поперечное по отношению к Приохотской зоне глубинных разломов ОЧВП.

\section{ХАРАКТЕРИСТИКА ОРУДЕНЕНИЯ ПОРФИРОВОЙ СИСТЕМЫ АКСУ}

Под порфировой системой в нашем случае мы, в соответствии со взглядами Р. Силлитое (Sillitoe, 2010), понимаем рудно-магматическую систему с типичным строением, где ядром являются диорит-порфириты, вмещающие Мооруденение (месторождение Аксу) и расположенные на флангах рудопроявления $\mathrm{Au}$ висмутового типа (рудопроявление Солнечное, на северо-западе) и Ag-полиметаллического типа (рудопроявление Высокое, на юго-западе) (см. рис. 1).

Краткая характеристика оруденения, образующего в целом порфировую систему, приведена в таблице.

Месторождение Аксу локализовано в центральной части Коркодоно-Наяханской тектономагматической зоны и приурочено к интрузивнокупольному поднятию общей площадью 150 км². Оно расположено к югу от массива Незаметный и имеет сложную морфологию (см. рис. 1). По геофизическим данным В. М. Каракозова и Б. А. Курашева (1990 г.) в центре рассматриваемой структуры находится невскрытый массив предположительно лейкократовых биотитовых гранитов или гранит-порфиров с низкими плотностными характеристиками $\left(2.55\right.$ г/с $\left.{ }^{3}\right)$. Минимальная глубина залегания верхней кромки массива в районе слияния руч. Маринка и Сабля составляет около 100 м (данные аэромагнитной съемки).

Молибденовое оруденение штокверкового типа занимает около 4 км². Вмещающие породы представлены преимущественно хурканской толщей $\mathrm{T}_{3} \mathrm{hr}$; юрские отложения $\mathrm{J}_{1-2} \mathrm{br}_{2}$ проявлены в восточной части. Осадочные породы прорваны небольшими штоками диорит-порфиритов наяханского интрузивного комплекса.

Рудная минерализация концентрируется преимущественно в центральной части штокверка и представлена типичными для Мо-порфировых систем кварц-молибденитовыми прожилками мощностью 0.1-5.0 см. Кварц серый тонкозернистый с мелкочешуйчатым молибденитом. Имеются находки тонких (1 мм) кварц-молибденитовых прожилков, секущих кварц-арсенопиритовые жилы. Прожилки установлены как в роговиках, так и в диорит-порфиритах. В самих же порфиритах, непосредственно в породе, также отмечается вкрапленность молибденита. В южной и восточной частях месторождения Аксу преобладает жильный тип. Жилы имеют преимущественно северо-восточное простирание (мощность жил достигает 0.8-1 м, протяженность до 150 200 м). Они характеризуются полосчатой текстурой и развитием крупночешуйчатого молибденита до $1.5 \%$. Концентрация Мо в подобных жилах -0.124 \% (Савва и др., 2014)*.

* Рассматриваемые в этой статье коркодоно-наяханские руды ошибочно отнесены к Конгинской гряде. 


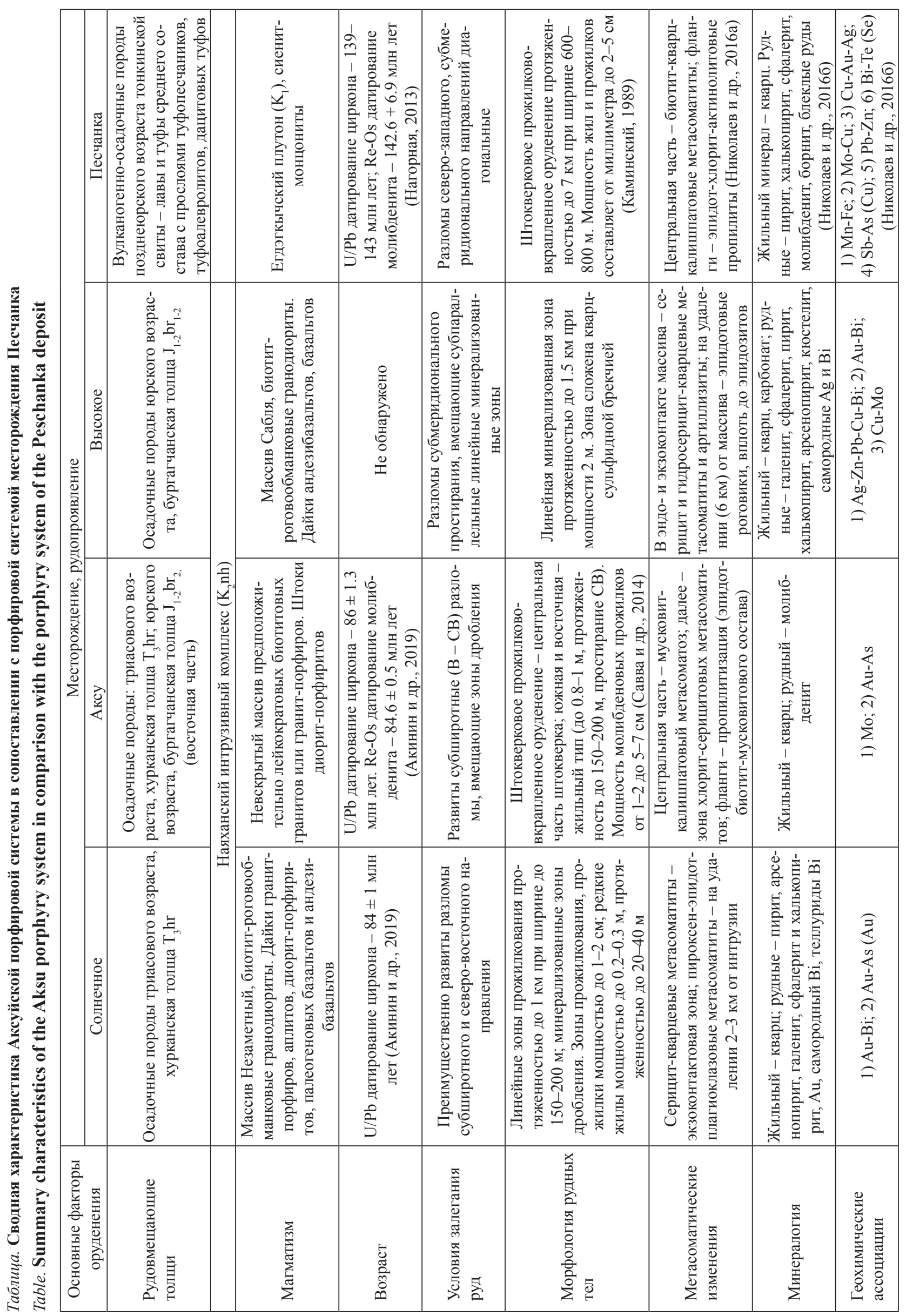


Проявления золоторудной минерализации в молибденитовом штокверке Аксу установлены в центральной части и на флангах - в кварцевых брекчиях. На левобережье руч. Прав. Аксу и Сабля установлены содержания $\mathrm{Au}$ до 0.6 г/т, $\mathrm{As}$ - до $1 \%$ и более, $\mathrm{Sb}$ - до $0.04 \%$.

Вмещающие породы в различной степени ороговикованы и метасоматически переработаны с формированием ареалов калиевого метасоматоза в центральной части и хлорит-серицитового и пропилитового на флангах.

Мусковит-калишпатовые метасоматиты. Их формирование отмечается в зоне субширотного направления длиной до 8 км и шириной около 2-3 км, сложенной различными литотипами пород. Преобразования заключаются в развитии мусковита как в призальбандовых частях, так и в микротрещинах кварцевых прожилков; кварцкалишпатовых прожилков; в замещении кластогенной части калиевыми полевыми шпатами; в обогащении рудной минерализации (пирит, молибденит). В центральной части метасоматического ареала Аксу калиевый полевой шпат замещает магматический K-Na полевой шпат и развивается одновременно с кварцем, часто образует скопления в зальбандовых частях кварцевых прожилков. Макроскопически это светло-серые породы с микрогранобластовой, лепидобластовой, участками порфировой структурами, массивной текстурой. Главными породообразующими минералами являются мусковит, кварц, калишпат; второстепенными - биотит, хлорит, пироксен, гранат. Акцессорные - рутил, апатит, сфен. Часто в породах отмечаются прожилки кварцевого состава различной направленности, с приуроченностью к ним крупночешуйчатого мусковита (рис. 2, $а, б$ ).

Хлорит-серицитовые метасоматиты тесно примыкают к зоне мусковит-калишпатовых и отличаются небольшим увеличением содержаний хлорита. Метасоматиты характеризуются частичным (до полного) замещением первичных темноцветных минералов хлоритом, а плагиоклаза - серицитом с отложением пирита.

Пропилитовые метасоматиты эпидот-биотит-мусковитового состава широко распространены в краевых частях штокверка и в провесах кровли интрузивного массива Сабля. При этом эпидот заполняет трещины, замещает полевые шпаты, часто образует ксенобластовые скопления. Исходные породы представлены обычно осадочными, реже интрузивными комплексами. Породы характеризуются порфиробластовой, лепидогранобластовой структурами; массивной, сланцеватой, пятнистой текстурами. Главные минералы - эпидот, пироксен, мусковит, гранат, карбонаты; сопутствующие - пирит, актинолит, гематит, гетит.

Результаты минералогического изучения на приборе QEMSCAN подтверждают высокие концентрации мусковита-серицита (34.2214.3 мас. \%) и калиевого полевого шпата (7.22$28.11 \%$ ) при их обратном соотношении, что характерно для порфировых систем. Мусковитсерицит и входит в состав полевошпат-кварцмусковитового матрикса, и образует тонкие оторочки кварцевых микропрожилков (рис. 3, a). Калишпат встречается в оторочках микропрожилков кварца в виде локальных скоплений и образует собственные прожилки и мономинеральную пятнистую вкрапленность (см. рис. $3, \sigma, в)$. Для центральной части Аксу отмечается высокое содержание кислого плагиоклаза (альбита) 10.99-6.39 мас. \%, что также характерно и для восточного фланга (см. рис. 3, 2), где он в ассоциации с кварцем слагает равномерный тонкозернистый агрегат (см. рис. 3, в).
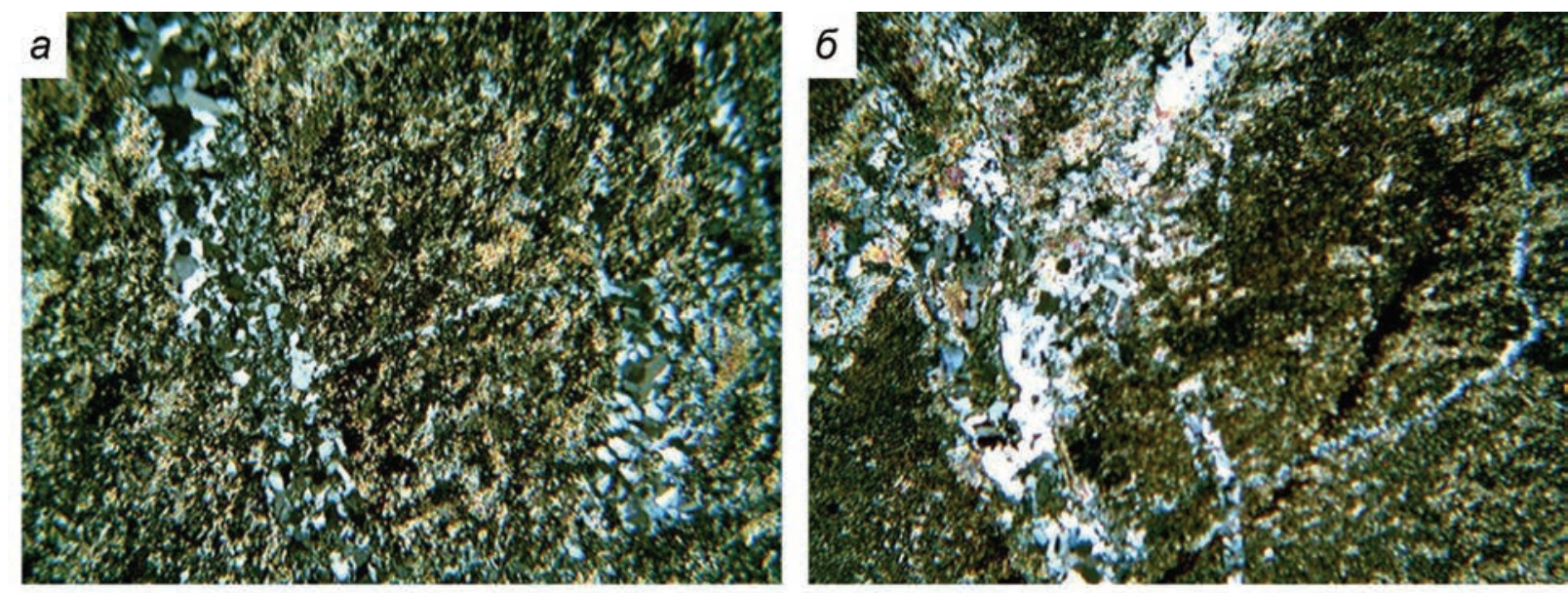

Puc. 2. Мусковит-калишпатовые метасоматиты. Шлиф: объектив 2.5, с анализатором

Fig. 2. Muscovite-kalifeldspar metasomatites. Thin section: 2.5 lens, with analyzer 

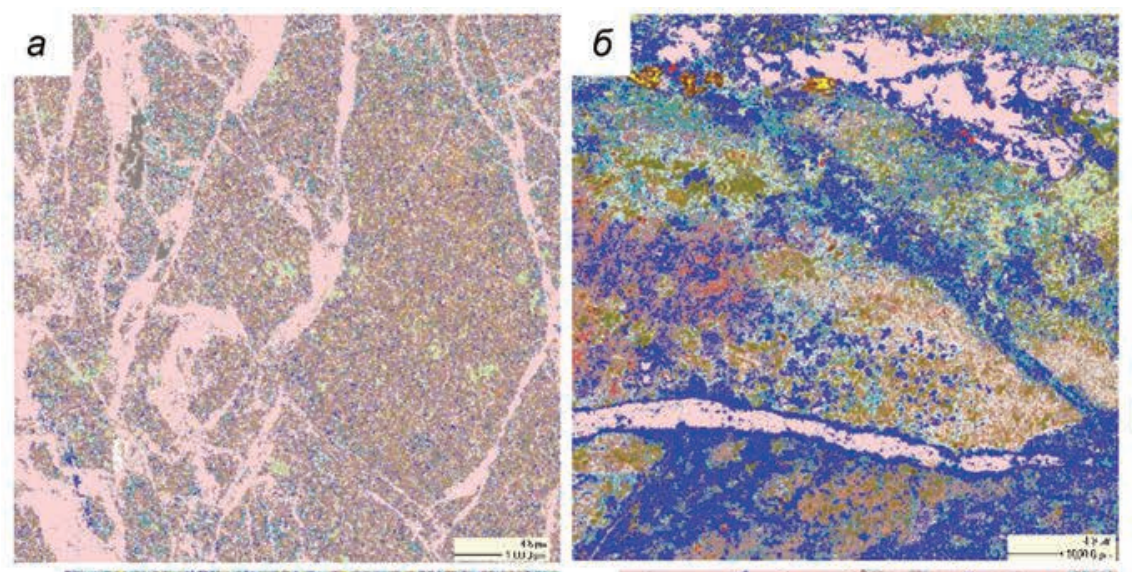

$\square$ Основа
$\square$ Пирит
$\square$ Пирротин
$\square$ Молибденит
$\square$ Халькопирит
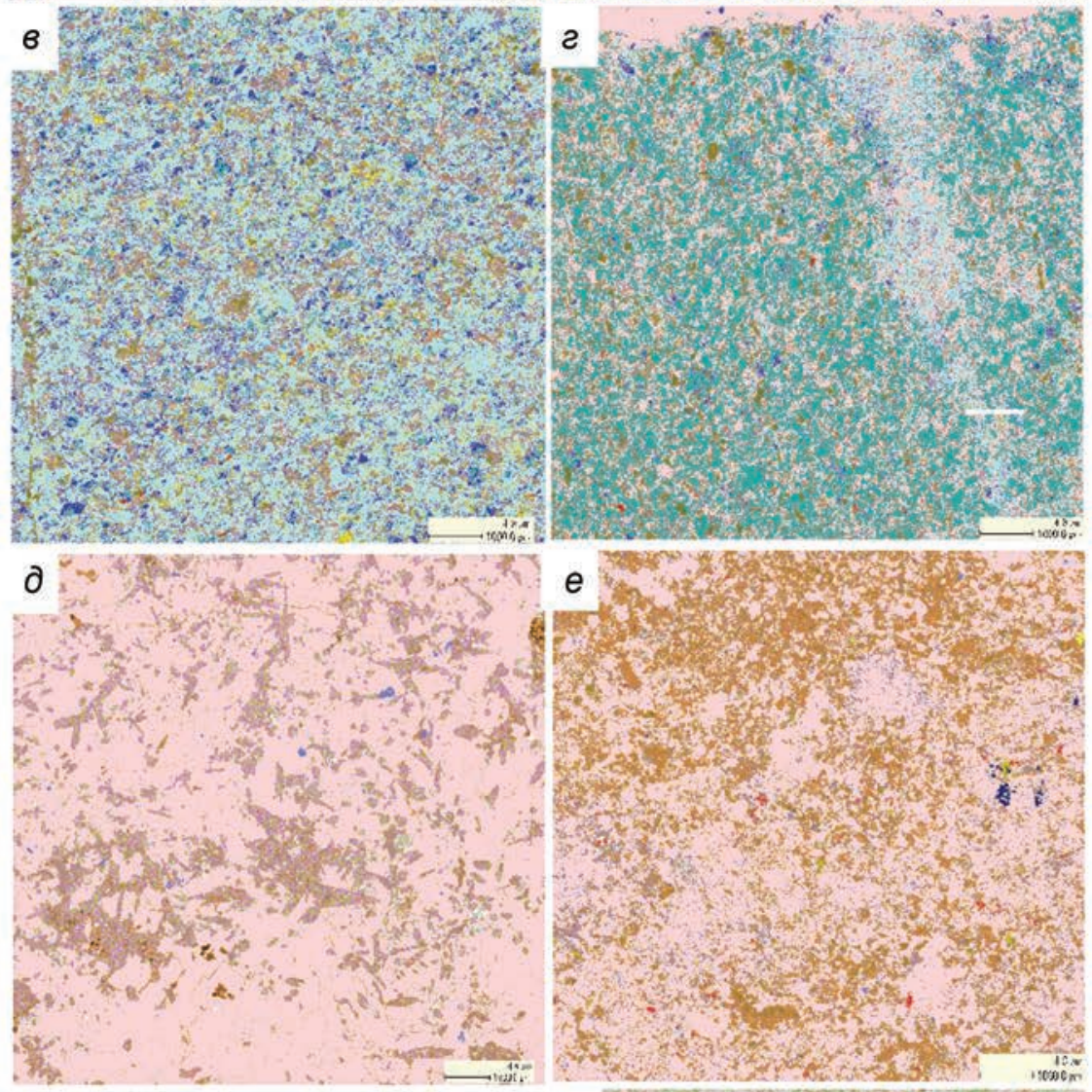

$\square$ Сфалерит

$\square$ Пнроксен-салит

$\square$ Калишпат

$\square$ Мусковит-серицит

$\square$ Кварц

Бнотит

Альбит

Плагиоклаз

$\square$ Хлорит

Андалузит

Рутил

Лимонит

$\square$ Глинистые минералы

Marнетит

Гранат

Ильменит

Турмалин

Сфен

Карбонаты

$\square$ Корунд

Апатит

$\square$ Гетит

$\square$ Пироксен (En-Fs)

$\square$ Сидерит

Гематит

$\square$ Амфибол

$\square$ Ставролит

$\square$ Эпидот

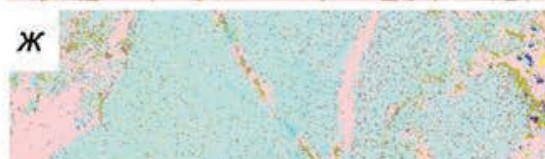

3

3

Монацит

$\square$ Циркон

$\square$ Другие мннералы
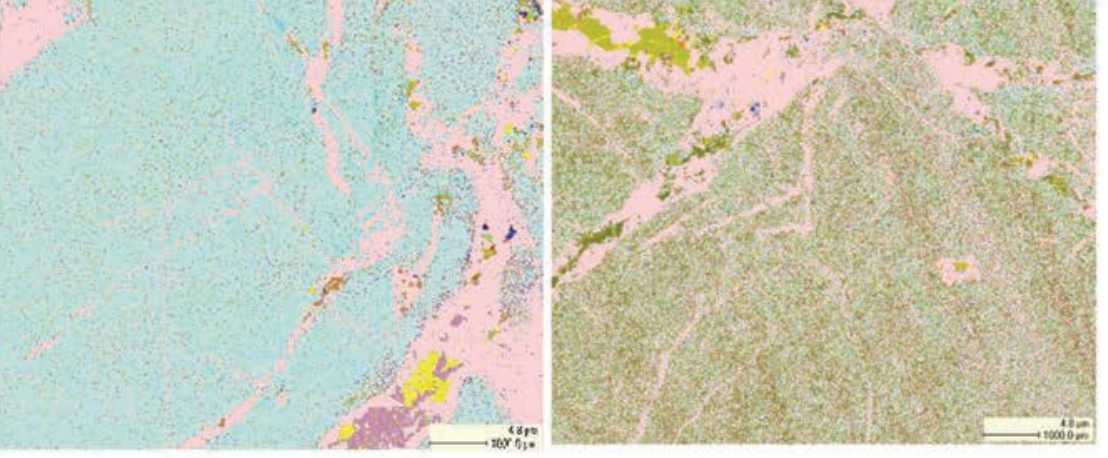

Puc. 3. Минеральный состав образцов по результатам QEMSCAN: $a, \sigma$ - центр Аксу; 6,2 - восточный фланг Аксу; $\partial, e$ - рудопроявление Высокое; ж- западный фланг Аксу; з - рудопроявление Солнечное

Fig. 3. Mineral composition of samples according to QEMSCAN results: $a$, $\sigma$-Aksu center; $b, 2-$ Aksu east flank; $\partial, e$-Vysokoye ore occurence; $ж$ - Aksu west flank; 3 - Solnechnoye ore occurrence 
Геохимическими исследованиями установлено, что центральная часть порфировой системы (штокверк Аксу) в плане характеризуется развитием моноэлементной молибденовой ассоциации, фиксирующей положение центральной части молибденового штокверка (Маматюсупов, Михалицына, 2016). Пробы, относящиеся к этой ассоциации, можно разделить на две группы: преимущественно молибденовые с содержанием Мо до 50-200 × 10-3\% и молибден-мышьякзолотые (Мо до $5 \times 10^{-3} \%$; As - до $100 \times 10^{-3} \%$; $\mathrm{Au}-$ до 1.4 г/т).

Рудопроявление Солнечное (северо-западный фланг порфировой системы Аксу) локализовано в триасовых отложениях на контакте с массивом Незаметный (см. рис. 1) и представлено в центральной части осадочными отложениями хурканской толщи, в северной и южной частях - отложениями сугойской толщи. Ocaдочные породы образуют пологие линейные складки восток-северо-восточного простирания и прорваны средне-, крупнозернистыми биотитроговообманковыми гранодиоритами массива Незаметный. Контакты массива сложные, с апофизами и наклонены в сторону вмещающих пород под углом около $10^{\circ}$. Ширина ореола экзоконтактовых изменений массива достигает 4 км. Он рассечен дайками гранит-порфиров, аплитов наяханского комплекса, дайками позднемеловых диорит-порфиритов, а также дайками палеогеновых базальтов и андезибазальтов. Дайки гранитпорфиров пересечены дайками аплитов. Взаимоотношений даек базальтов и аплитов не наблюдалось.

В структуре рудопроявления Солнечное сочетаются две системы разломов - субширотного и северо-восточного направления. К разломам суб- широтного направления приурочены линейные зоны кварцевого, сульфидно-кварцевого прожилкования и минерализованные зоны дробления.

Рудные тела представлены зонами прожилкования протяженностью до 1 км при ширине до 150-200 м и разноориентированными нитевидными прожилками мощностью до 1-2 см. По составу выделяются кварцевые, кварц-хлоритовые, сульфидно-кварцевые и кварц-хлорит-сульфидные прожилки. Зоны рудной минерализации в основном связаны с разломами субширотного, реже северо-восточного простирания. Содержание сульфидов в породах в среднем составляет 3-5 \%, иногда до 15-20\%. Они представлены пиритом (преобладает), мелкозернистым арсенопиритом, реже галенитом, сфалеритом и халькопиритом. В агрегатах арсенопирита устанавливается широкое развитие включений с золотовисмутовой минерализацией.

На рудопроявлении Солнечное установлен Au-редкометалльный тип (Савва и др., 2014), представленный тонковкрапленной золотосульфидной минерализацией в ороговикованных осадочных толщах триаса. На северозападном фланге проявления отмечены две геохимические ассоциации - $\mathrm{Au}-\mathrm{Bi}$ и $\mathrm{Au}-\mathrm{As}(\mathrm{Au})$ co свободным золотом (Маматюсупов, Михалицына, 2016).

Гидротермальные преобразования, развитые в экзоконтактовой зоне массива Незаметный, представлены серицит-кварцевыми метасоматитами с кварцевым прожилкованием и рудной минерализацией (пирит, халькопирит). На удалении (в 2-3 км) от интрузии развиты метасоматиты пироксен-эпидот-плагиоклазового состава (рис. 4, a), западнее (в 4 км) в кварцплагиоклазовых роговиках отмечается вклю-
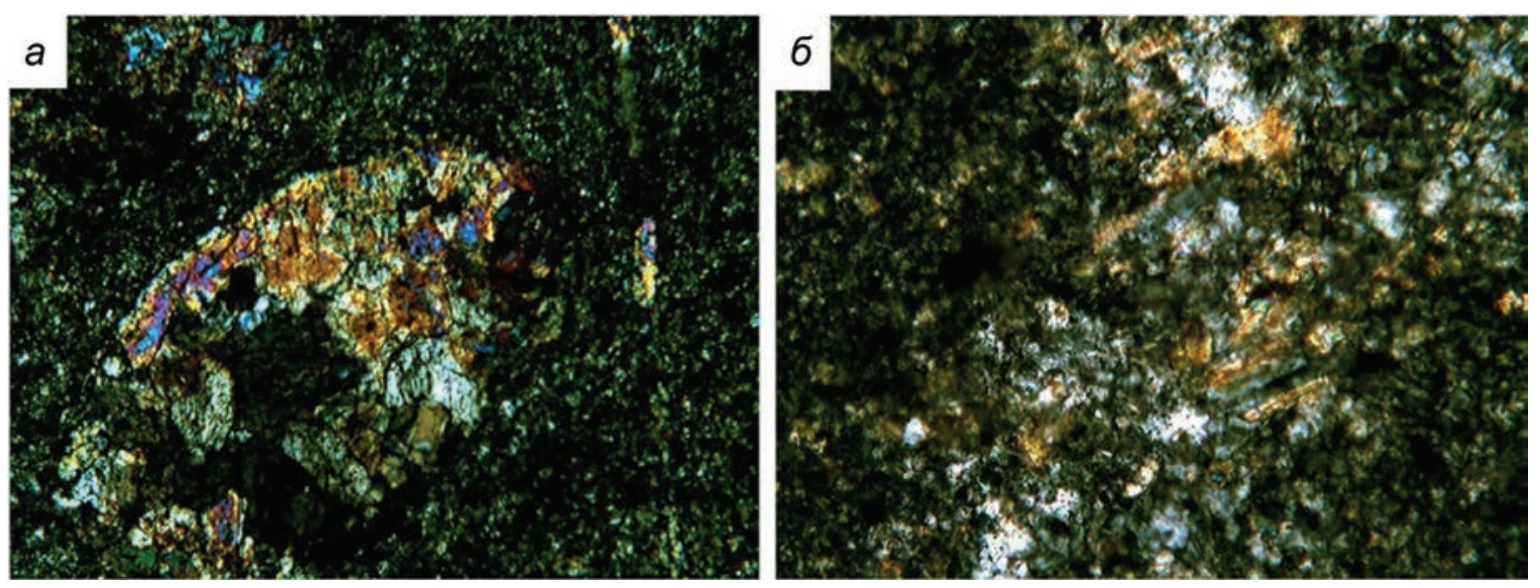

Puc. 4. Метасоматиты: $a$ - пироксен-эпидот-полевошпатового состава; $\sigma$ - кварц-актинолит-хлоритовые прожилки в кварц-полевошпатовых роговиках; рудопроявление Солнечное. Шлиф, объектив 20, с анализатором

Fig. 4. Metasomatites: $a$ - of pyroxene-epidote-feldspar composition; $\sigma$ - quartz-actinolite-chlorite bodies in quartzfeldspar hornfelses; Solnechnoye ore occurrence. Thin section, lens 20, with analyzer 
чение кварц-актинолит-хлоритовых прожилков (рис. 4, б).

Серицит-квариевые метасоматиты характеризуются микрогранолепидобластовой и слабо выраженной сланцеватой текстурой. Главные минералы - кварц, плагиоклаз (альбит-олигоклаз), калинатровый полевой шпат, серицит, биотит; второстепенные - карбонаты (кальцит); акцессорные - сфен, рутил.

В метасоматитах пироксен-эпидот-плагиоклазового состава отмечаются кварцевые микропрожилки и сростки с альбитом; главные минералы - кварц, полевые шпаты, эпидот, пироксен, амфиболы (актинолит), гранат. На фоне матрикса породы выделяются удлиненные округлые порфиробласты, выполненные пироксеном, с развитием по нему эпидота в виде кристаллобластических зерен, имеющих резко выраженные извилистые и зубчатые ограничения. По периферии порфировых образований развиты каемки, содержащие амфибол (актинолит); единично встречаются редкие мелкие зерна граната, развитого по эпидоту (рис. $4, a$ ).

По данным, полученным на приборе QEMSCAN, пироксен-салит и актинолит составляет от 10 до $31.2 \%$, заполняет микротрещины, образует порфиробласты, агрегатные скопления различной формы; эпидот - 4.66-17.81 мас. \%, который развивается в виде агрегатных скоплений (до 0.5 мм) и тонких просечек в основной массе; полевые шпаты - 14.51-32.89 мас. \%; по всему матриксу породы отмечается биотит 16.5 мас. \% как в виде мелкой сыпи, так и крупных чешуек, образующих агрегатные скопления. Также в количестве 5 мас. \% установлен гранат (гроссуляр?) (см. рис. 3 , з). Часто с биотитом связаны акцессорные минералы (монацит, рутил, ильменит, сфен), несущие повышенные содержания редких элементов.

Рудопроявление Высокое расположено на юго-востоке внешней фронтальной зоны интрузивно-купольного поднятия Аксу, в провисе кровли между гранитоидными массивами Сабля и Безымянный (см. рис.1). Рудовмещающие породы представлены преимущественно осадочными и вулканогенно-осадочными отложениями бургагчанской толщи юрского возраста $\left(\mathrm{J}_{1-2} \mathrm{br}_{1}\right.$, $\mathrm{J}_{1-2} \mathrm{br}_{2}$ ). Массив Сабля сложен среднезернистыми биотит-роговообманковыми гранодиоритами. Западные и восточные контакты массива погружаются на восток под углами 40-50. Здесь отмечены дайки андезибазальтов, базальтов. Вмещающие отложения в экзоконтактовой зоне шириной 200-300 м преобразованы в роговики.

На рудопроявлении Высокое распространен Ag-полиметаллический тип руд, который представлен прожилками и гнездами галенит- сфалерит-халькопиритового состава в кварце и карбонате с небольшим количеством арсенопирита. Согласно данным Л. И. Ртищевой (2014 г.), они сосредоточены в линейной зоне северо-северо-западного простирания, вмещающей в себя серию субпараллельных участков, связанных с разломами субмеридионального простирания. Ее протяженность достигает 1.5 км при мощности 2 м. Она представлена кварц-сульфидными брекчиями: сульфид, галенит и сфалерит, реже - пирит, халькопирит и арсенопирит - образуют неоднородные зернистые массы, сцементированные кварцем. Сульфидность руд достигает 80 \%. Золото низкопробное, представлено кюстелитом, находится в тесной ассоциации с галенитом. Значительно интенсивнее развито самородное серебро, нередко в ассоциации с самородным висмутом. Золото-серебряное отношение может достигать 1:100.

В геохимическом плане рудопроявление Высокое характеризуется развитием сереброполиметаллической геохимической ассоциации: Ag - до 200 г/т, Zn - 200-1000 × 10-3\%, $\mathrm{Pb}-300-1000 \times 10^{-3} \%, \mathrm{Cu}-50-200 \times 10^{-3} \%$, $\mathrm{Bi}$ - до $50 \times 10^{-3} \%$ при низких концентрациях As - до 50-100 × 10-3\%. На западном фланге установлены Au-Bi ассоциация с содержаниями $\mathrm{Au}$ более 2 г/т и $\mathrm{Bi}$ - до $100 \times 10-3 \%$, а также $\mathrm{Cu}-\mathrm{Mo}$ ассоциация с содержанием $\mathrm{Cu}$ до $300 \times$ $10^{-3} \%$ и Мо до $5 \times 10^{-3} \%$.

В эндо- и экзоконтактах массива породы метасоматически изменены до серицит, гидросерицит-кварцевых метасоматитов и аргиллизитов. Метасоматиты приурочены преимущественно к субмеридиональным и субширотным нарушениям либо к их пересечению.

Оквариеевание, альбитизация и двуслюдяные роговики отмечаются в северной и восточной частях рудопроявления Высокое (рис. 5).

Они сопровождают сульфидно-кварцевые прожилки (пирит, молибденит). Двуслюдяные роговики характеризуются микрогранобластовой структурой, пятнистой текстурой. Основной базис породы состоит из мелкочешуйчатого биотита и серицита, пелитовых глинистых частиц, микроскопических (0.05 мм и менее) кристаллобластовых зерен плагиоклаза, кварца, эпидота. На его фоне выделяются порфировые образования кварца с развитием мусковита (рис. 5, б). Нередко в роговиках встречаются секущие кварцевые прожилки с включениями рудной минерализации.

Филлитизациия и сульфидизация отмечаются в междуречье Сабля - Ольховый. Сульфиды, как правило, концентрируются в центральных частях существенно кварцевых, кварцкалишпатовых прожилков (см. рис. 3 , ж), иногда 

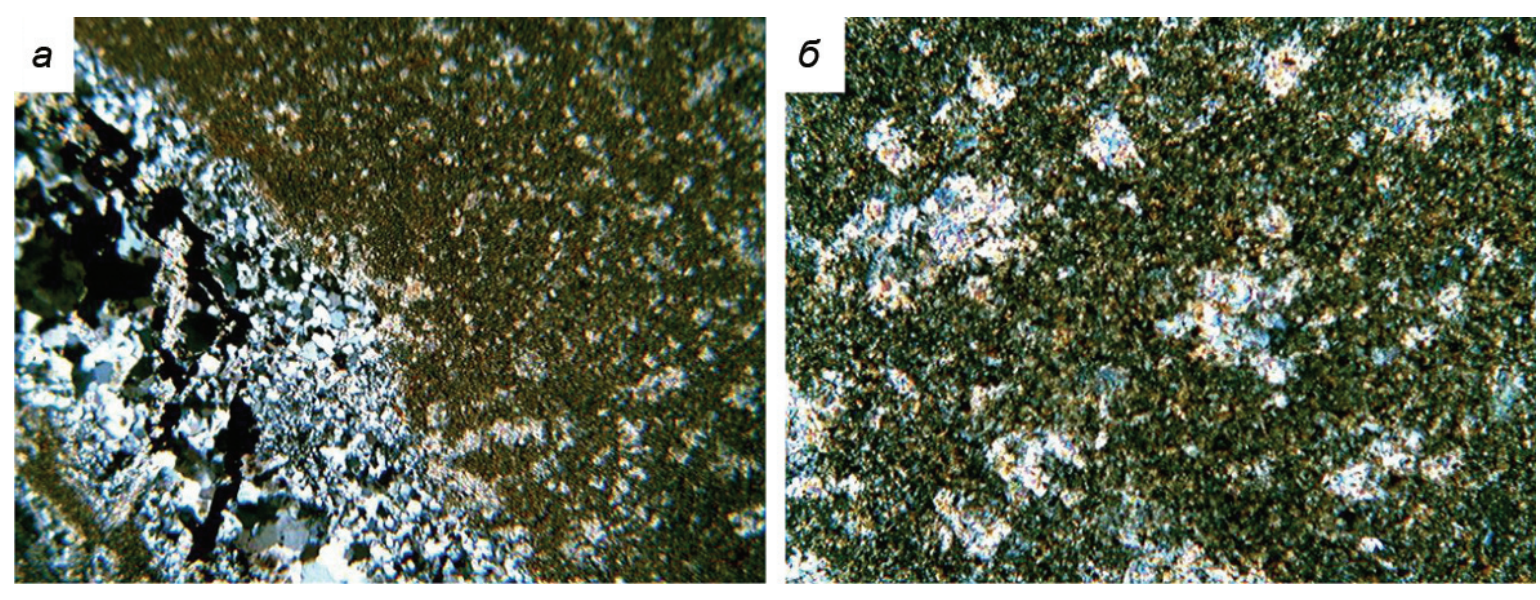

Puc. 5. Двуслюдяной роговик с сульфидно-кварцевым прожилком на рудопроявлении Высокое: $a$ - объектив $2.5 ; \sigma$ - объектив $10 ;$ с анализатором

Fig. 5. Two-mica hornfels with a sulphide-quartz venlet at the Vysokoye ore occurrence: $a$-lens 2.5 ; $\sigma$ - lens 10 , with analyzer

они образуют рассеянную равномерную вкрапленность (см. рис. 3, в, $\partial, e)$ в метасоматитах. Минералами-индикаторами метасоматитов, по данным QEMSCAN, являются кварц (55.5$63.3 \%)$, лимонит (4.8-21.6\%) и серицит (5.1$7.1 \%)$, развивающийся пятнами по основной массе породы (см. рис. 3, $\partial, e$ ).

Пропилитизачия и аргиллизачия выявлены ранее проведенными геологоразведочными работами (Л. И. Ртищева, 2014 г.) на рудопроявлении Высокое.

\section{ОБСУЖДЕНИЕ РЕЗУЛЬТАТОВ ИССЛЕДОВАНИЙ}

Формирование многофазных интрузий гранитоидов наяханского комплекса и связанного с ними молибден-порфирового оруденения происходило длительное время, при неоднократных метаморфогенных и метасоматических преобразованиях пород. По данным датирования U-Pb SHRIMP-методом установлено, что возраст кристаллов цирконов составил $84 \pm 1$ млн лет в гранодиоритах массива Незаметный и $86 \pm 1.3$ млн лет - в диоритах штока Аксу (Акинин и др., 2019); Re-Os датировка молибденита из Аксу $84.6 \pm 0.5$ млн лет, что говорит об их генетическом родстве.

По степени и характеру вторичных изменений вулканогенно-осадочных пород на рассматриваемой территории установлена определенная последовательность метаморфических и метасоматических преобразований: региональный динамометаморфизм (хлорит-серицит) $\rightarrow$ контактовый метаморфизм (биотит, кварц, кордиерит) $\rightarrow$ пневматолитово-гидротермальнометасоматические изменения (мусковит-серицит, эпидот, полевые шпаты, кварц-турмалиновые прожилки и гнезда).
Результаты качественного петрографического и количественного изучения метасоматитов с использованием QEMSCAN позволяют наметить следующую минералогическую зональность метасоматитов (от центра к периферии): центральная часть (штокверк Аксу) - мусковиткалишпатовый метасоматоз $\rightarrow$ фланги (в 2-3 км от центра) - эпидотовый метасоматоз (пропилиты $) \rightarrow$ удаленные части (3-5 км) - серициткварцевый тип метасоматоза (пропилиты).

На диаграмме распределения минераловиндикаторов в рудовмещающих метасоматитах порфировой системы Аксу (рис. 6), как и на многих месторождениях данного типа (Sillitoe, 2010), видно, что максимальные концентрации мусковита и калиевого полевого шпата приурочены к ядру системы, на удалении от которого развиты эпидот, пироксен, гранат. Окварцевание, альбитизация (в виде прожилков) отмечаются по всей площади, с более интенсивным проявлением на флангах системы.

Согласно модели R. H. Sillitoe (2010), в центральной части порфировых систем располагается безрудное кварцевое ядро, далее - зона калишпатизации, сложенная плагиоклазами и биотитом, затем следует зона филлизитизации с серицитом, кварцем и пиритом, которую сменяет зона аргиллизитизации с алунитом, каолином и пиритом. Все это обрамляют поля пропилитизированных пород (хлорит, эпидот, кальцит и пирит). В метасоматических ореолах широко развиты разнообразные системы кварцевых жил. Оруденение приурочено к границе зоны калишпатизации и филлизитизации (кварц-серицитовые метасоматиты). Порфировая система Аксу совмещает фрагменты нескольких типов оруденения и включает медно-порфировые месторождения, приуроченные к интрузиям; удаленные 


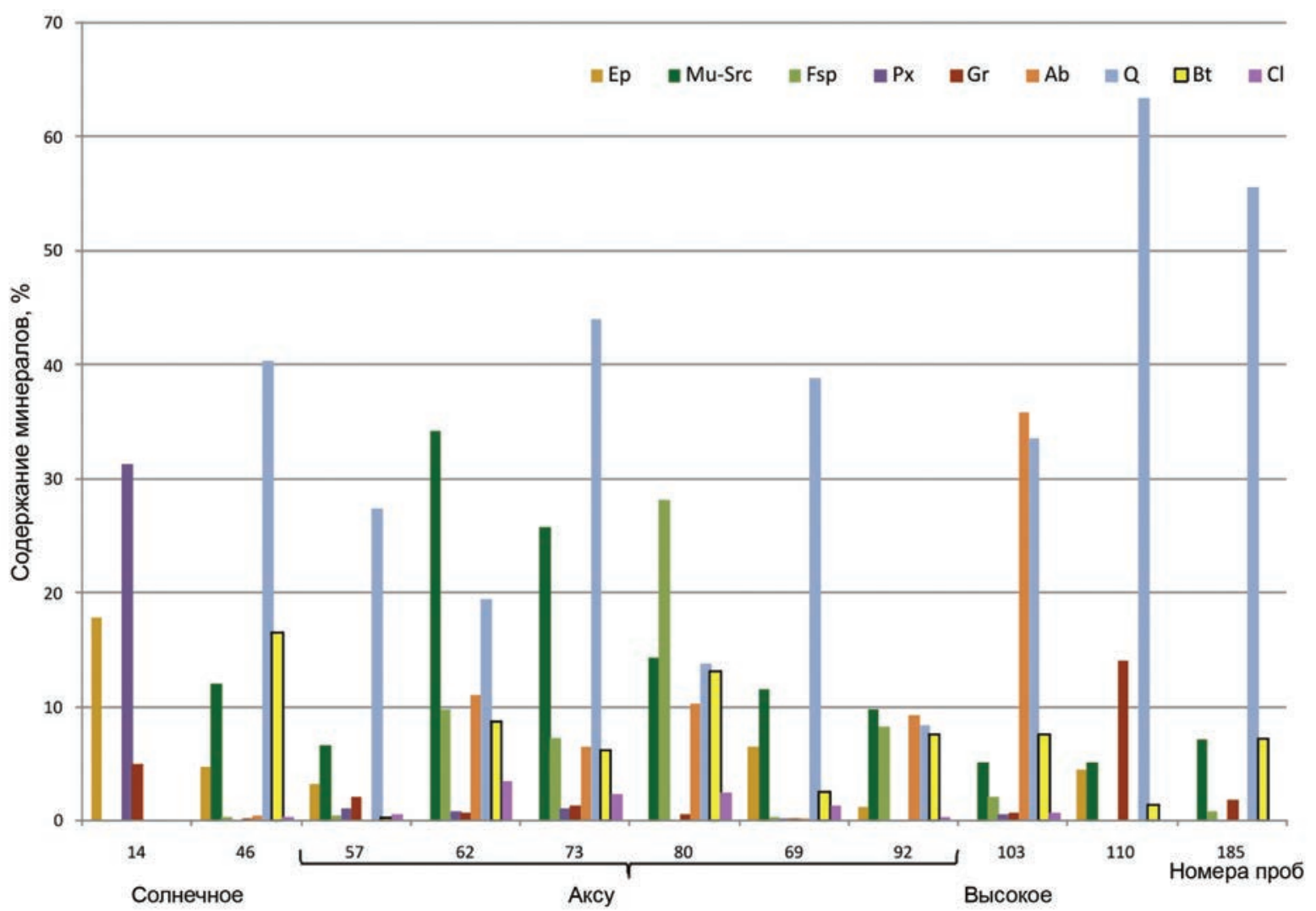

Puc. 6. Распределение минералов-индикаторов в метасоматитах по данным QEMSCAN. Примечание. По оси абсцисс - номера образцов (прозрачных шлифов) по профилю; по оси ординат - количественное содержание минералов, слагающих метасоматиты. Ер - эпидот, Mu-Src - мусковит-серицит, Fsp - калиевый полевой шпат, $\mathrm{Px}$ - пироксен, $\mathrm{Gr}$ - гроссуляр, $\mathrm{Ab}$ - альбит, Q - кварц, $\mathrm{Bt}$ - биотит, $\mathrm{Cl}$ - хлорит

Fig. 6. Distribution of indicating minerals in metasomatites, according to QEMSCAN. Note: Horizontal axis shows sample numbers (transparent sections) by profile; vertical axis, quantitative content of minerals, composing metasomatites. Ep - epidote, Mu-Src - muskovite-sericite, Fsp - K-feldspar, Px - pyroxene, Gr - grossular, Ab - albite, $\mathrm{Q}$ - quartz, $\mathrm{Bt}$ - biotite, $\mathrm{Cl}$ - chlorite

полиметаллические руды (скарны), сереброполиметаллические и золото-серебряные месторождения, локализованные на несущественном удалении или над медно-порфировыми штокверками.

Типовым примером классической зональности метасоматических изменений служит крупное медно-порфировое месторождение Песчанка (см. таблицу), где выявленная рудная минерализация расположена в контуре биотит-калишпатовых метасоматитов, которые на флангах месторождения сменяются эпидотхлорит-актинолитовыми пропилитами по монцодиоритам и вмещающим их ороговикованным вулканогенно-осадочным породам. Рудная зональность представлена борнитовым ядром, промежуточной халькопиритовой зоной и внешней пиритовой оболочкой, совпадающей с пропилитами (Читалин и др., 2016).

Помимо классических примеров зональности, существуют месторождения с неполной зональностью, например, Шахтаминское месторождение (Восточное Забайкалье), где про- явлена следующая последовательность метасоматических процессов - ранняя калишпатизация, затем окварцевание и серицитизация с развитием по периферии хлоритизации, а в ряде случаев отмечается аргиллизация (Берзина и др., 2013).

Изученная нами порфировая система Аксу характеризуется следующим строением: ядро Мо-порфировый тип (месторождение Аксу), сопровождающийся мусковит-калишпатовым метасоматозом (рис. 7). В отличие от классической схемы R. H. Sillitoe (2010), аргиллизиты здесь отсутствуют из-за среднерудного эрозионного среза, в то время как в более эродированной части (северо-западный фланг) эффект такого среза еще более увеличивается и на поверхность выходят относительно более высокотемпературные метасоматические изменения. Так, на площади рудопроявления Солнечное наблюдаются процессы грейзенизации, где высокотемпературные изменения фиксируются также и по гранатовым роговикам (см. рис. 6). Характерно развитие крупночешуйчатого мусковита в виде пятен по 


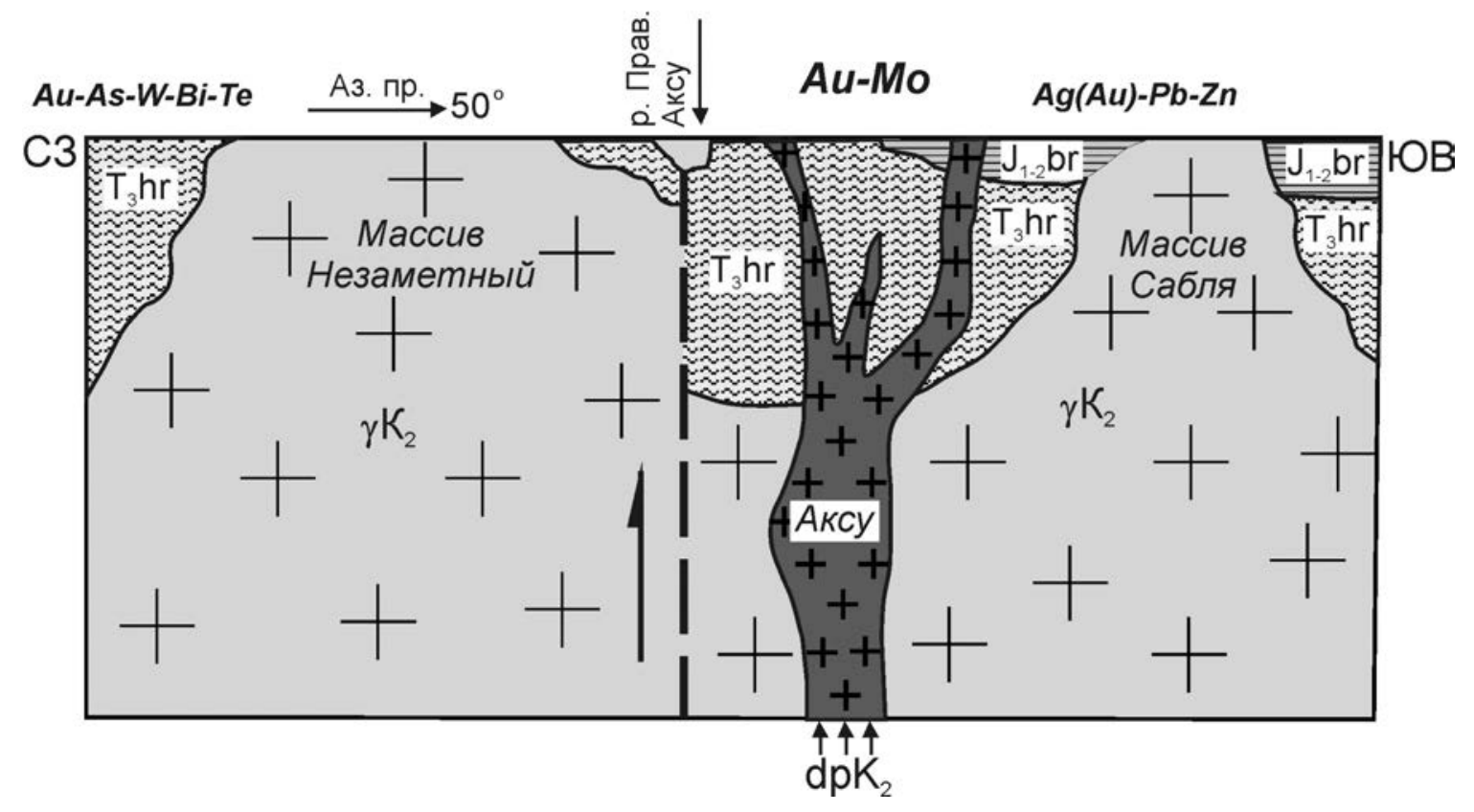

Puc. 7. Принципиальная модель Аксуйской порфировой системы

Fig. 7. Conceptual model of the Aksu porphyry system

основной массе породы, которые могут отражать возможную связь данного рудопроявления с порфировой системой Аксу.

Прослеживание метасоматической зональности в юго-восточном направлении (площадь рудопроявления Высокое) показывает менее эродированную часть (средне-, верхнерудный уровень) порфировой системы Аксу, о чем свидетельствует закартированная при геологической съемке зона не только пропилитизированных, но и аргиллизированных пород (Л. И. Ртищева, 2014 г.). Прямым свидетельством связи этих метасоматитов с единой порфировой системой служит обнаружение молибденита в метасоматитах рудопроявления Высокое в его фланговых частях.

Таким образом, в результате комплексных исследований мы определили метасоматическую зональнось порфировой системы Аксу и выявили ее асимметрию, связанную с блоковым строением территории в разной степени эрозии (см. рис. 1,7$)$. Месторождение Аксу в этом контексте обнаруживает черты сходства с Шахтаминским месторождением (Берзина и др., 2013). Рудная и геохимическая зональность подтверждают эту асимметрию: Аu-редкометалльный комплекс (рудопроявление Солнечное) с $\mathrm{Au}-\mathrm{Bi}$ (As, Cu) геохимической ассоциацией - на северо-западе, кварц-молибденитовый с Мо (Cu, Au) геохимической ассоциацией - в центре и серебросвинцово-цинковый с $\mathrm{Ag}-\mathrm{Pb}-\mathrm{Zn}(\mathrm{Cu}, \mathrm{Bi}, \mathrm{As}, \mathrm{Au})$ ассоциацией - на юго-востоке (рудопроявление Высокое).

Выявленные элементы метасоматической и геохимической зональности подтверждают су- ществование единой рудообразующей системы порфирового типа, обычной для позднемеловых - кайнозойских вулкано-плутонических поясов обрамления Пацифика (Sillitoe, 2005). Магматическим фактором локализации продуктов данной рудообразующей системы является ее позиция в провисе кровли крупного позднемелового (по данным K/Ar датирования) монцонитоидного батолита осевой части КоркодоноНаяханского ряда, что обусловило широкое распространение золото-висмутовой ассоциации минералов и элементов, поскольку этот тип оруденения характерен для экзоконтактовых зон таких массивов.

\section{ЗАКЛЮЧЕНИЕ}

Настоящим исследованием показано, что комплексное, в том числе количественное, изучение минералов метасоматитов с составлением минеральных карт в характеристическом изучении элементов может значительно облегчить такой важный аспект в изучении порфировых систем. Изучение метасоматической зональности месторождения Аксу по петрографическому профилю в автоматическом режиме на аппаратно-программном комплексе дало положительный результат. Выявлены концентрически-зональные изменения в центральной части системы (от центра к периферии): кварц-мусковит-калишпатовые $\rightarrow$ альбит-актинолит-эпидотовые. Подобная метасоматическая зональность обычна для порфировых месторождений. В региональном 
плане установлена асимметричность метасоматической зональности, связанная с разной степенью эрозии тектонических блоков строения изученной площади. В отличие от классических моделей молибден-порфировых месторождений с полнопроявленной зональностью, на месторождении Аксу пострудный кварцкаолинит-смектитовый горизонт практически полностью эродирован и появляется только на юго-восточном фланге.

В результате установлена последовательность формирования рудно-магматической системы Аксу: I - формирование золото-висмутовых руд в контактах гранодиоритового плутона Незаметный; II - внедрение штоков диоритов и интенсивный калишпатовый и эпидотактинолитовый метасоматоз с формированием молибден-порфировых руд в центральной части площади; III - завершение порфирового оруденения характеризуется формированием сателлитных рудообразующих зон преимущественно на юго-восточном фланге, сопровождаемых серицит-полевошпатовым метасоматозом и формированием золото-сереброносных полиметаллических руд.

Полученные нами материалы дают основание предполагать, что в пределах внешнего контура системы Аксу, возможно, залегают слепые рудные тела, обогащенные молибденом, золотом и серебром, связанные с сателлитами штока Аксу под аргиллизитами.

\section{ЛИТЕРАТУРА}

Акинин В. В., Колова Е. Е., Савва Н. Е., Горячев Н. А., Маматюсупов В. Т., Кузнеиов В. М., Альшевский $A$. В., Ползуненков Г. О. Возраст гранитоидов и ассоциирующего молибден-порфирового оруденения Коркодоно-Наяханской зоны, Северо-Восток России // Вестник Северо-Восточного научного центра ДВО РАН. 2019. № 4. С. 3-8.

Берзина А. П., Берзина А. Н., Гимон В. О., Крымский Р. Ш., Ларионов А. Н., Николаева И. В., Серов П. А. Шахтаминская Мо-порфировая рудно-магматическая система (Восточное Забайкалье): возраст, источники, генетические особенности // Геология и геофизика. 2013. Т. 54, № 6. С. 764-786.

Каминский В. Г. Комплексная геолого-поисковая модель медно-порфирового месторождения Баимской зоны // Советская геология. 1989. № 11. С. 46-56.

Китаев H. A. Многомерный анализ геохимических полей. Новосибирск : Наука, Сиб. отд-ние, 1990. 119 с.

Кривцов А. И. Геологические основы прогнозирования и поисков медно-порфировых месторождений. Москва : Недра, 1983. 256 с.

Кривцов А. И., Мигачев И. Ф., Попов В. С. Меднопорфировые месторождения мира. Москва : Недра, 1986. $236 \mathrm{c}$.
Кузнеиов В. М., Гагиев М. Х., Дылевский Е. Ф., Михайлова В. П., Палымская 3. А., Шашурина И. Т., Шевченко В. М., Шпикерман В. И. Геологическая карта и карта полезных ископаемых Колымо-Омолонского региона. Масштаб 1:500 000 : объяснит. записка. Магадан : СВКНИИ ДВО РАН, 1998. 270 с.

Маматюсупов В. Т., Михалицььна Т. И. Минералого-геохимическая характеристика порфировой системы Аксу // Геология, география, биологическое разнообразие и ресурсы Северо-Востока России : Материалы III Всерос. конф., посвящ. памяти А. П. Васьковского и в честь его 105-летия (Магадан, 12 14 окт. 2016 г.). Магадан : СВКНИИ ДВО РАН, 2016. C. 164-166.

Нагорная E. B. Минералогия и зональность молибден-медно-порфирового рудного поля Находка, Чукотка : автореф. дис. ... канд. геол.-минер. наук. Москва, 2013. 28 с.

Николаев Ю. Н., Бакшеев И. А., Прокофьев В. Ю., Нагорная Е. В., Марущенко Л. И., Сидорина Ю. Н., Читалин А. Ф., Калько И. А. Аu-Ag минерализация порфирово-эпитермальных систем Баимской зоны (Западная Чукотка, Россия) // Геология рудных месторождений. 2016а. Т. 58, № 4. С. 319-345.

Николаев Ю. Н., Джеджея Г. Т., Сидорина Ю. Н., Калько И. А. Геохимическая зональность Песчанкинской порфирово-эпитермальной системы (Западная Чукотка) // Разведка и охрана недр. 2016б. № 11. C. 41-46.

Парфенов Л. М. Континентальные окраины и островные дуги в мезозоидах северо-востока Азии. Новосибирск : Наука, 1984. 192 с.

Рид С. Дж. Б. Электронно-зондовый микроанализ и растровая электронная микроскопия в геологии. Москва : Техносфера, 2008. 232 с.

Савва Н. Е., Ртищева Л. И., Рочева В. К. Типы золоторудной минерализации в пределах Конгинской гряды (Северо-Восток России) // Геология и минерально-сырьевые ресурсы Северо-Востока России : Материалы Всерос. науч.-практ. конф. 1-3 апреля 2014 г. Якутск, 2014. С. 419-423.

Скибин Б. П. Медно-молибденовое оруденение Северного Приохотья // Советская геология. 1982. № 2. C. $78-85$.

Читалин А. Ф., Николаев Ю. Н., Бакшеев И. А., Прокофьев В. Ю., Фомичев В. Е., Усенко В. В., Нагорная Е. В., Марущенко Л. И., Сидорина Ю. Н., Джеджея $Г$. Т. Порфирово-эпитермальные системы Баимской рудной зоны, Западная Чукотка // Смирновский сборник-2016. Проблемы минерагении, экономической геологии и минеральных ресурсов. Москва : Макс Пресс, 2016. С. 82-114.

Sillitoe R. H. The tops and bottoms of porphyry copper deposits // Economic Geology. 1973. No. 6. P. 799-815.

Sillitoe $R . H$. Supergene oxidized and enriched porphyry copper and related deposits // Economic Geology One Hundredth Anniversary. Vol. 1905-2005. 2005. P. 723-768.

Sillitoe R. H. Porphyry copper systems // Economic Geology. 2010. Vol. 105. P. 3-41. 


\title{
ORE-METASOMATIC ZONALITY OF THE AKSU MOLYBDENUM-PORPHYRY SYSTEM (North-East Asia)
}

\author{
O. T. Sotskaya, T. I. Mikhalitsyna, N. E. Savva, N. A. Goryachev, V. T. Mamatyusupov, \\ F. I. Semishev, M. A. Malinovsky
}

\begin{abstract}
North-East Interdisciplinary Scientific Research Institute n. a. N. A. Shilo, FEB RAS, Magadan
The article presents the data from a comprehensive study of the Aksu Mo-porphyry system metasomatites (Korkodon-Nayakhan magmatic activation zone). The halo of metasomatic changes around the porphyry system, associated with the tectonic-block structure of the territory, is shown to be asymmetric. The core of the system is brought to the surface and located in a halo of kalifeldsparmuscovite metasomatites; the northwestern block is elevated and characterized by high-temperature epidote-biotite and epidote-pyroxene propylites, while in the southeastern block there is a consistent transition from kalifeldspar-sericite metasomatites to fragments of argillisite ones. The established zoning is confirmed by geochemical associations and mineralization types from the northwest to the southeast: in the northwest, $\mathrm{Au}-\mathrm{Bi}(\mathrm{As}, \mathrm{Cu})$ at the Solnechnoye ore occurrence; in the center, $\mathrm{Mo}(\mathrm{Cu}, \mathrm{Au})$ at the Aksu deposit; in the southeast, $\mathrm{Ag}-\mathrm{Pb}-\mathrm{Zn}(\mathrm{Cu}, \mathrm{Bi}, \mathrm{As}, \mathrm{Au})$ at the Vysokoye ore occurrence.
\end{abstract}

Keywords: metasomatites, Mo-porphyry system, geochemistry, Magadan Oblast.

\section{REFERENCES}

Akinin, V. V., Kolova, E. E., Savva, N. E., Goryachev, N. A., Mamatyusupov, V. T., Kuznetsov, V. M., Alshevsky, A. V., Polzunenkov, G. O., 2019. Age of Granitoids and the Associated Molybdenum-Porphyry Mineralization in the Korkodon-Nayakhan Zone, North-East of Russia, Bulletin of the North-East Science Center. 4, 3-8 [In Russian].

Berzina, A. P., Berzina, A. N., Gimon, V. O., Krymsky, R. Sh., Larionov, A. N., Nikolayeva, I. V., Serov, P. A., 2013. Shakhtaminskaya Mo-Porphyry Ore-Magmatic System (Eastern Trans-Baikalia): Age, Sources, Genetic Features, Russian Geology and Geophysics. 54, 6, 764-786 [In Russian].

Chitalin, A. F., Nikolayev, Yu. N., Baksheyev, I. A., Prokofyev, V. Yu., Fomichev, V. E., Usenko, V. V., Nagornaya, E. V., Marushchenko, L. I., Sidorina, Yu. N., Dzhedzheya, G. T., 2016. Porphyry-Epithermal Systems of the Baimsk Ore Zone, Western Chukotka, Problems of Minerageny, Economic Geology, and Mineral Resources (Smirnovsky Collection 2016). Moscow, Max Press. 82-115 [In Russian].

Kaminsky, V. G., 1989. Complex Geological-Prospecting Model of the Baimsk Zone Copper-Porphyry Deposit, Sovetskaya Geologiya. 11, 46-56 [In Russian].

Kitayev, N. A., 1990. Multidimensional Analysis of Geochemical Fields. Novosibirsk, Nauka, Siberian Branch [In Russian].

Krivtsov, A. I., 1983. Geological Foundations of Forecasting and Prospecting for Copper-Porphyry Deposits. Moscow, Nedra [In Russian].

Krivtsov, A. I., Migachev, I. F., Popov, V. S., 1986. Copper-Porphyry Deposits of the World. Moscow, Nedra [In Russian].

Kuznetsov, V. M., Gagiyev, M. H., Dylevsky, E. F., Mikhailova, V. P., Palymskaya, Z. A., Shashurina, I. T.,
Shevchenko, V. M., Shpikerman, V. I., 1998. The Geological Map and the Mineral Map of the Kolyma-Omolon Region. Scale 1: 500.000. Explanatory Note. Magadan, NEISRI FEB RAS [In Russian].

Mamatyusupov, V. T., Mikhalitsyna, T. I., 2016. Mineralogical and Geochemical Characteristics of the Aksu Porphyry System, Geology, Geography, Biological Diversity, and National Resources of Russia's North-East. The 3rd All-Russia Conference in Commemoration of A. P. Vaskovsky and in Dedication of His 105th Anniversary (Magadan, October 12-14, 2016). Conference Proceedings. Magadan, NEISRI FEB RAS. 164-166 [In Russian].

Nagornaya, E. V., 2013. Mineralogy and Zonality of the Molybdenum-Copper-Porphyry Ore Field, Chukotka : Avtoref. Dis. ... Candidata Geol.-Miner. Nauk. Moscow [In Russian].

Nikolayev, Yu. N., Baksheyev, I. A., Prokofyev, V. Yu., Nagornaya, E. V., Marushchenko, L. I., Sidorina, Yu. N., Chitalin, A. F., Kalko, I. A., 2016. Au-Ag Mineralization of Porphyry-Epithermal Systems in the Baimsk Zone (Western Chukotka, Russia), Geology of Ore Deposits. 58, 4, 319-345 [In Russian].

Nikolayev, Yu. N., Dzhedzheya, G. T., Sidorina, Yu. N., Kalko, I. A., 2016. Geochemical Zonality of the Peschanka Porphyry-Epitermal System (Western Chukotka), Prospect and Protection of Mineral Resources . 11, 41-46 [In Russian].

Parfyonov, L. M., 1984. Continental Margins and Island Arcs in the Mesozoids of Northeast Asia. Novosibirsk, Nauka [In Russian].

Reed, S. J. B., 2008. Electron-Probe Microanalysis and Scanning Electron Microscopy in Geology. Moscow, Technosphera [In Russian]. 
Savva, N. E., Rtishcheva, L. I., Rocheva, V. K., 2014. Types of Gold Mineralization within the Kongin Ridge (North-East of Russia), Geology and Mineral Resources in the North-East of Russia. Materials in the All-Russia Scientific and Practical Conference, April 1-3, 2014. Yakutsk. 419-423 [In Russian].

Sillitoe, R. H., 1973. The Tops and Bottoms of Porphyry Copper Deposits, Economic Geology. 6, 799815.
Sillitoe, R. H., 2005. Supergene Oxidized and Enriched Porphyry Copper and Related Deposits, Economic Geology One Hundredth Anniversary Vol. 1905-2005. 723-768.

Sillitoe, R. H., 2010. Porphyry Copper Systems, Economic Geology. 105, 3-41.

Skibin, B. P., 1982. Copper-Molybdenum Mineralization of the Northern Priokhotye, Sovetskaya Geologiya. 2, 78-85 [In Russian]. 